\title{
Stabiilization and Improvement of Black Cotton Soil by using Additives
}

\author{
A.A.Gudadhe \\ Dept. of Civil Engineering, \\ Datta Meghe Institute of Engineering, Technology \& \\ Research Wardha, India
}

\author{
A. D. Deshmukh \\ Dept. of Civil Engineering \\ Government Polytechnic \\ Yavatmal, India
}

\begin{abstract}
Swelling soils, which are clayey soils, are also called expansive soils. They increase in volume with the addition of water. They shrink greatly on drying and develop cracks on the surface. These soils possess a high plasticity index. Black cotton soils found in many parts of India belong to this category. The main disadvantages of this type of soil are that multistorage construction is not possible and cracks are formed in the superstructure. The proposed work is meant for to know that which additives as a binder will be helpful for the stabilization of the soil. For this we proposed the consistency and UCS test and thus Coconut and sugarcane ash act as a beneficial binder for soil stabilization.
\end{abstract}

\section{Keywords—Black Cotton Soil, Stabilization, Additives}

\section{INTRODUCTION}

The structures especially lightly loaded, founded on such deposits exhibit various distresses, deformations and damages, sometimes even collapse of the structures also. As reported in $1993 £ 150$ million in the UK, $\$ 1000$ million in the USA \& in India tens of millions of rupees are spent on repairs, maintenance and rehabilitation of damaged structures. Pure BC Soil also called as swell-shrink soils. It exhibits large cyclic volumetric changes during dry-wet seasons. It has very high compressibility and having very low bearing capacity. In the field construction activities, expansive soils are used either as a construction material or as a foundation material.

The swelling soils in India has their origin in subaqueous decomposition of basalt rocks or weathering In-Situ. It is very necessary to discuss about the Engineering behavior of soils. From this information civil structures can be prevented from the damages causing Expansive soils.

- Inorganic Stabilization

- Lime Stabilization

- Mechanical Stabilization

- Chemical Stabilization

- Stabilization by Heating

- Electrical Stabilization

The overall objective of the research is to study the strength properties of stabilized soil as a function of soil conditions and type of binder. The general strength behavior and similarities/differences in strength properties has to be investigated in the laboratory for soft soils stabilized with various binders. The possible influence of the stress conditions, the evaluation of other properties of importance for an understanding of the strength behavior, such as water content, density, degree of saturation.

Various methods and approaches on expansive soil have started since 1959 . There are many evidences available of the problems created by these expansive soils. Till 1930 there were no remedies suggested to avoid swelling behavior of soil, although it was a common practice that framed buildings performed better than brick buildings, the reason for it was hardly understood. During the past two three decades much work has been done by various investigators and various theories have been proposed. Soils at lower water content swells when subjected to water contact are known as swelling soils and the phenomenon is known as 'swelling'.

\section{METHODOLOGY}

The percentage of organic additives added in pure BCS are as given below -

Sample (A) - Pure BCS

Sample (B) - BCS + 10\% Coconut Ash

Sample (C) - BCS + $20 \%$ Coconut Ash

Sample (D) - BCS + 10\% Sugarcane Ash

Sample (E) - BCS + $20 \%$ Sugarcane Ash

Sample (F) - BCS +10\% Fly Ash

Sample (G) - BCS +20\% Fly Ash

The various test conducted are Consistency test which includes Plastic Limit, Liquid Limit and Shrinkage Limit and Unconfined Compression test.

\section{CONSISTENCY TEST RESULT}

\begin{tabular}{|c|c|c|}
\hline Soil Sample & UCS & $\begin{array}{c}\text { \% increase in } \\
\text { UCS }\end{array}$ \\
\hline Sample A(100\%BCS) & $1.820 \mathrm{~kg} / \mathrm{cm} 2$ & $99.72 \%$ \\
\hline $\begin{array}{c}\text { Sample B(BCS+10\% } \\
\text { sugarcane Ash }\end{array}$ & $03.605 \mathrm{~kg} / \mathrm{cm} 2$ & $144.32 \%$ \\
\hline $\begin{array}{c}\text { Sample C(BCS+20\% } \\
\text { Sugarcane Ash \%) }\end{array}$ & $4.410 \mathrm{~kg} / \mathrm{cm} 2$ & $5.31 \%$ \\
\hline $\begin{array}{c}\text { Sample D(BCS+10\%fly } \\
\text { Ash) }\end{array}$ & $1.910 \mathrm{~kg} / \mathrm{cm} 2$ & $18 \%$ \\
\hline $\begin{array}{c}\text { Sample E(BCS+20\% Fly } \\
\text { Ash) }\end{array}$ & $2.130 \mathrm{~kg} / \mathrm{cm} 2$ & $8.74 \%$ \\
\hline $\begin{array}{c}\text { Sample F(BCS+10\% } \\
\text { Coconut Ash) }\end{array}$ & $02.141 \mathrm{~kg} / \mathrm{cm} 2$ & $7.97 \%$ \\
\hline $\begin{array}{c}\text { Sample F(BCS+20\% } \\
\text { Coconut Ash) }\end{array}$ & $1.661 \mathrm{~kg} / \mathrm{cm} 2$ & \\
\hline
\end{tabular}

\section{STABILIZATION TECHNIQUE USED IN INDIA}

Road construction in India faces the big challenge of having to complete huge projects in the shortest possible construction time. Thousands of new road kilometres are 
needed and will be built over the next years to expand the network of traffic arteries in the booming economy. This requires fast-paced, reliable and economical construction processes. Soil stabilization meets these requirements.

In the construction of National Highway no :7 in large scale the stabilization of ground is done by fly ash because a large no of fly ash waste was generated in Nagpur from the factories and industries.

\section{CONCLUSION}

Addition of Sugarcane and coconut ash sharply decreases the Liquid Limit and plastic Limit values and increases the shrinkage limit. From these decreased values of liquid limit and plastic limit we can conclude that the swelling characteristic of black cotton soil is reduced. And the good result is obtained in addition of coconut ash and sugarcane ash when mix in proportion $10 \%$ and $20 \%$.
Addition of coconut ash and sugarcane ash sharply increases the strength values in term of UCS. The value of UCS is increased approximately $20 \%$ and $30 \%$.

When it is necessary for the compaction point of view in respective area sugarcane ash would be very beneficial as it has the great result in the UCS.

\section{REFERENCES}

[1] Babu Shankar, N. et al. (1998): 'Chemical stabilization of expansive clay slopes', Proc. IGC-1998, IIT New Delhi.

[2] Ground improvement and soil stabilization techniques of Ancient India by Dr, A.S. Nene.

[3] Additives to Clay: Minerals and Synthetic Additives Practical Action Technical Brief

[4] Petry T. M. and Little D. N. (2002): “ Review of stabilization of clays and expansive soils in pavements and lightly loaded structures: history, practice and future" Proc., of Journal of Materials in Civil Engineering, ASCE, 14, No. 6, 447-460.

[5] Indian Standard Code (1977) : IS : 2720 ( Part XI) 